\title{
EFEKTIVITAS RUANG TERBUKA HIJAU SEBAGAI HABITAT BURUNG DI KOTA BOGOR DAN SEKITARNYA
}

\section{Effectivity of Green Open Spaces as Bird Habitats in Bogor City and Its Surroundings}

\section{Sry Wahyuni}

Mahasiswa Sekolah Pascasarjana IPB, Program Studi Arsitektur Lanskap

Email : srywahyuniii@gmail.com

\section{Syartinilia}

Staf Pengajar Departemen Arsitektur Lanskap, Fakultas Pertanian IPB

\section{Yeni Aryati Mulyani}

Staf Pengajar Departemen Konservasi

Sumberdaya Hutan dan Ekowisata, Fakultas Kehutanan IPB

\begin{abstract}
Green open spaces can be potential habitats for birds in urban landscapes. Due to high number of land development, the green open spaces in urban landscapes tend to be small and scattered. Indeed, analysis about effectivity of green open spaces as bird habitats in Bogor City and its surroundings is needed. We investigated bird habitat patches on 14 locations in Bogor City and its surroundings. This study aimed to analyze the effectiveness of bird habitat patches for bird species richness using two variables (size and complexity). The data were analyzed using the Pearson Correlation and multiple linear regression. The results showed that there were no significant differences between bird species richness and size of patches. Conversely, there were significant differences between bird species richness and complexity of patches. The Pearson Correlation revealed that there were high correlation between bird species richness and complexity of patches. Finally, we propose three recommendations of green open spaces as bird habitat patches in Bogor City and its surroundings, such as protecting and managing both small and large bird habitat patches, increasing number of vegetation strata and number of vegetation in some strata in small bird habitat patches, and increasing number of vegetation in some strata in large bird habitat patch with low bird speciess richness.
\end{abstract}

Key words: Complexity, landscape management, size of patch, species richness

\section{PENDAHULUAN}

\section{Latar Belakang}

Lanskap perkotaan merupakan lanskap yang identik dengan area yang luas dan padat serta didominasi oleh ruang terbangun dengan variasi struktur beragam (Simonds dan Starke, 2006; Nilon et al., 2003). Menurut Irwan (2005), perkembangan wilayah perkotaan di Indonesia cenderung mengarah pada kondisi yang dapat menimbulkan beragam masalah lingkungan dan mengakibatkan terganggunya keseimbangan lingkungan tersebut. Kota Bogor merupakan salah satu kota di Indonesia yang terus mengalami perkembangan dengan tingkat pertumbuhan penduduk dan pembangunan fisik kota yang cukup tinggi. Jika perkembangan ini tidak diseimbangkan dengan penataan dan pembangunan lanskap perkotaan yang berwawasan lingkungan maka akan mengakibatkan terjadinya degradasi lingkungan.

Upaya peningkatan kualitas dan kuantitas ruang terbuka hijau diharapkan dapat mendukung pelestarian vegetasi dan satwa liar yang ada di dalamnya. Burung merupakan salah satu satwa liar yang banyak ditemukan di lanskap perkotaan dan dapat dijadikan sebagai salah satu indikator kualitas dan perubahan lingkungan (Furness et al., 1993; Koskimies, 1989; Parsons, 2007). Upaya peningkatan kualitas dan kuantitas ruang terbuka hijau ini merupakan isu penting dan telah menjadi perhatian utama dalam usaha melindungi lingkungan alami, khususnya di lanskap perkotaan (Chiesura, 2004).

Berdasarkan beberapa penelitian terdahulu, terdapat kecenderungan penurunan jumlah jenis burung dari tahun ke tahun di Kota Bogor. Pada periode tahun 1932-1952, Diamond et al. (1987) mencatat sebanyak 62 jenis burung ditemukan di Kebun Raya Bogor dan mengalami penurunan yang cukup signifikan pada periode tahun 1980-1985, yaitu tercatat hanya 43 jenis burung. Selanjutnya, berdasarkan penelitian yang dilakukan oleh Sukara et al. (2014), tercatat sebanyak 48 jenis burung terdapat di Kebun Raya Bogor. Hal ini mengindikasikan telah terjadinya perubahan kualitas lingkungan di Kota Bogor.
Ruang terbuka hijau di lanskap perkotaan cenderung berupa habitat-habitat bervegetasi yang berukuran kecil (patch) dengan lokasi yang menyebar (Carbó-Ramírez dan Zuria, 2011; Dramstad et al., 1996; Nichol et al., 2010; Strohbach et al., 2013). Kondisi serupa juga terjadi di lanskap Kota Bogor dan sekitarnya. Menurut Dramstad et al. (1996), habitat yang berbentuk patch-patch tersebut memiliki ancaman isolasi habitat yang lebih tinggi dan meningkatkan kemungkinan terjadinya kepunahan spesies. Meskipun demikian, ruang terbuka hijau yang berbentuk patch-patch tersebut memiliki nilai ekologis penting dan dapat dimanfaatkan oleh burung sebagai habitat yang dapat mendukung kelangsungan hidupnya (CarbóRamírez dan Zuria, 2011; Strohbach et al., 2013). Selain itu, patch habitat berukuran kecil juga dapat mendukung spesies yang tidak biasa dan memfasilitasi pergerakan spesies dari satu patch ke patch lainnya (Dramstad et al., 1996).

Kajian mengenai keberadaan ruang terbuka hijau sebagai habitat burung masih terus berkembang. Keberadaan Kebun Raya Bogor dan taman-taman publik serta bentuk ruang terbuka hijau lain di sekitarnya memiliki potensi sebagai habitat burung di Kota Bogor. Beberapa tahun terakhir, Kota Bogor telah berupaya membangun taman-taman dan bentuk ruang terbuka hijau lainnya yang diharapkan dapat berfungsi sebagai habitat burung. Namun, keberadaan ruang terbuka hijau sebagai patch habitat burung ini perlu dianalisis lebih lanjut terkait dengan efektivitasnya, apakah ruang terbuka hijau tersebut berfungsi optimal untuk mendukung kelangsungan hidup burung.

Minimnya informasi bagi arsitek lanskap dan pihak-pihak terkait mengenai ruang terbuka hijau yang efektif sebagai patch habitat burung di lanskap perkotaan menjadi alasan kuat dilakukannya penelitian ini. Umumnya, kajian mengenai ruang terbuka hijau sebagai habitat burung di bidang arsitektur lanskap di kota-kota di Indonesia adalah sebatas mengidentifikasi keanekaragaman jenis burung dan hubungannya dengan keanekaragaman jenis vegetasi (Endah dan Partasasmita, 2015; Setiawan et al., 2006). Penelitian ini 
bertujuan menganalisis efektivitas delapan tipe ruang terbuka hijau sebagai patch habitat burung di Kota Bogor dan sekitarnya. Hasil dari penelitian ini diharapkan dapat digunakan sebagai informasi dasar dan acuan bagi berbagai pihak khususnya arsitek lanskap dan pengelola Kota Bogor dalam melakukan perencanaan dan pengelolaan ruang terbuka hijau sebagai habitat burung di lanskap perkotaan.

\section{METODE PENELITIAN}

\section{Lokasi dan Waktu Penelitian}

Penelitian ini dilaksanakan di ruang terbuka hijau di Kota Bogor dan sekitarnya dengan luas wilayah sebesar 11915.71 ha. Secara astronomis, Kota Bogor terletak pada koordinat 106 $48^{\prime}$ BT dan 6026' LS. Bentuk ruang terbuka hijau yang dijadikan sebagai fokus penelitian ini adalah kebun raya, hutan penelitian, ecopark, jalur hijau jalan, hutan kota, taman, lapangan, dan tempat pemakaman umum (TPU). Penelitian ini dilaksanakan dari November 2015 hingga Agustus 2016.

\section{Metode Penelitian}

\section{Pengumpulan Data}

Kekayaan Jenis Burung

Pengamatan burung dilakukan dengan menggunakan metode daftar jenis MacKinnon (MacKinnon lists method) yang dianjurkan oleh Robertson dan Liley (1998) dan Bibby (2004). Pada penelitian ini pengamatan dilakukan dengan mencatat seluruh data perjumpaan dengan burung, mencakup jenis, lokasi keberadaan, dan aktivitasnya ketika diamati. Selain itu, pengamatan juga dilakukan dengan mencatat jenis burung unik di masing-masing lokasi. Jenis burung unik adalah jenis burung yang hanya dijumpai di satu lokasi. Pada setiap lokasi yang diamati, dilakukan pengamatan mulai pukul 06.00-18.00 WIB. Pengamatan dilakukan sebanyak tiga kali ulangan pada hari yang berbeda. Pemberian nama jenis dan nama ilmiah burung yang dijumpai mengikuti tata nama Sukmantoro et al. (2007).

\section{Kekayaan Jenis Vegetasi}

Pengamatan vegetasi dilakukan dengan menggunakan metode penghitungan (counts method) yang dianjurkan oleh Bullock (2006). Pada penelitian ini pengamatan dilakukan dengan mencatat seluruh data vegetasi di lokasi, mencakup strata, jenis, jumlah jenis, keberadaan buah dan bunga. Pemberian nama jenis dan nama ilmiah vegetasi mengacu pada LIPI (2013). Selain itu, batasan strata vegetasi yang digunakan juga mengacu pada LIPI (2013) dengan modifikasi, yaitu pohon (A), perdu (B), semak (C), penutup tanah dan merambat (D), serta tumbuhan air (E).

\section{Analisis Efektivitas Patch Habitat}

Efektivitas patch habitat terhadap kekayaan jenis burung diperoleh dengan menghitung ukuran patch (besar atau kecil) dan kompleksitas patch (jumlah strata dan jumlah jenis vegetasi) (Gambar 1). Standar ukuran patch habitat mengacu pada hierarki ruang terbuka publik (CABE, 2009) dengan modifikasi, yaitu: 1) Patch habitat berukuran kecil, memiliki ukuran $<2$ ha dan 2) Patch habitat berukuran besar, memiliki ukuran $\geq 2$ ha. Hubungan antara kekayaan jenis burung dengan ukuran dan kompleksitas patch variabel jumlah strata serta jumlah jenis vegetasi diuji dengan menggunakan uji korelasi Pearson. Selain itu, analisis regresi linear berganda dilakukan untuk mengukur besarnya pengaruh yang diberikan oleh variabel patch habitat (ukuran dan kompleksitas patch) terhadap kekayaan jenis burung. Seluruh proses uji statistik dilakukan dengan menggunakan program SPSS 17.0. Hipotesis yang digunakan adalah:

$\mathrm{H} 0=$ Variabel ukuran dan kompleksitas patch tidak berpengaruh nyata terhadap kekayaan jenis burung

$\mathrm{H} 1$ = Variabel ukuran dan kompleksitas patch berpengaruh nyata terhadap kekayaan jenis burung

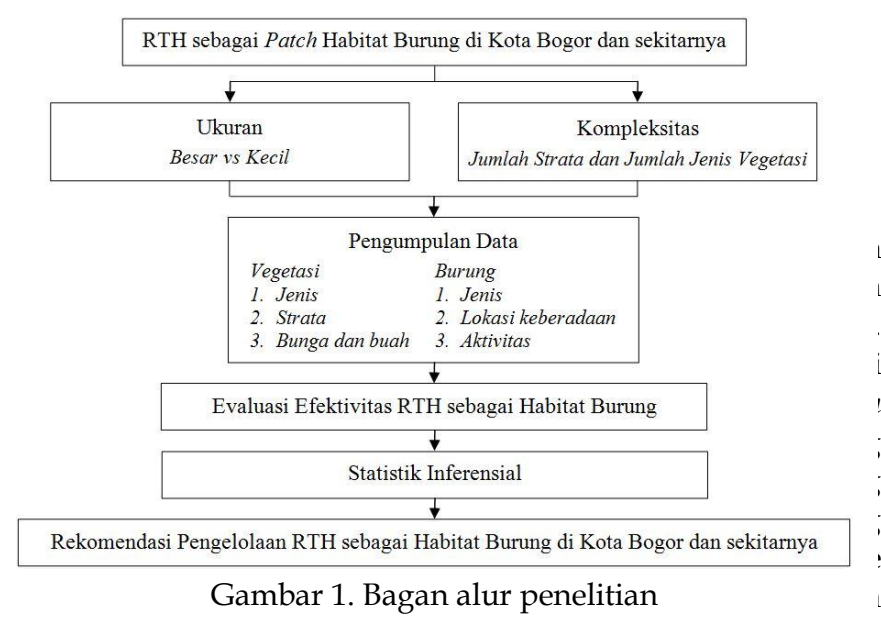

\section{HASIL DAN PEMBAHASAN}

\section{Hasil}

Menurut ukurannya, sebanyak tujuh patch dikategorikan sebagai patch habitat berukuran kecil dan tujuh patch lainnya dikategorikan sebagai patch habitat berukuran besar (Tabel 1). Selain itu, menurut kompleksitasnya, sebanyak 2 patch memiliki 3 strata vegetasi, 10 patch memiliki 4 strata vegetasi, dan 2 patch lainnya memiliki 5 strata vegetasi. Jumlah jenis burung yang tercatat di seluruh lokasi pengamatan adalah 70 jenis burung dari 33 suku (Tabel 2). Tiga suku burung terbanyak yang tercatat di seluruh lokasi pengamatan adalah Pycnonotidae (tujuh jenis burung), Sylviidae (enam jenis burung), dan Columbidae (lima jenis burung).

\section{Efektivitas Patch Habitat}

Seluruh patch habitat yang diamati memiliki luasan bervariasi, yaitu 0.27-81.5 ha. Berdasarkan hasil pengamatan pada patch habitat berukuran besar, jumlah jenis burung terbanyak 
Tabel 1 Kategori patch habitat, strata, dan jumlah jenis burung pada masing-masing lokasi

\begin{tabular}{|c|c|c|c|c|c|c|}
\hline \multirow{2}{*}{ No. } & \multirow{2}{*}{ Lokasi } & \multirow{2}{*}{$\begin{array}{l}\text { Luas } \\
(\mathrm{Ha})\end{array}$} & \multicolumn{2}{|c|}{ Kategori Patch Habitat } & \multirow{2}{*}{ Strata } & \multirow{2}{*}{$\begin{array}{l}\text { Jumlah Jenis } \\
\text { Burung }\end{array}$} \\
\hline & & & Ukuran & Kompleksitas & & \\
\hline 1 & Kebun Raya Bogor & 81.5 & Besar & 5 strata & A-B-C-D-E & 57 \\
\hline 2 & Sentul Boulevard & 33.71 & Besar & 5 strata & A-B-C-D-E & 15 \\
\hline 3 & Hutan Penelitian Dramaga & 60 & Besar & 4 strata & A-B-C-D & 20 \\
\hline 4 & Ecopark CSC LIPI & 32 & Besar & 4 strata & A-C-D-E & 28 \\
\hline 5 & TPU Dreded & 7.34 & Besar & 4 strata & A-B-C-D & 17 \\
\hline 6 & Taman Heulang & 2.8 & Besar & 4 strata & A-B-C-D & 17 \\
\hline 7 & Lapangan Sempur & 2.2 & Besar & 4 strata & A-B-C-D & 10 \\
\hline 8 & Hutan Kota Ahmad Yani & 1.32 & Kecil & 4 strata & A-B-C-D & 13 \\
\hline 9 & Lapangan Manunggal & 1.11 & Kecil & 4 strata & A-B-C-D & 17 \\
\hline 10 & Taman Kencana & 0.56 & Kecil & 4 strata & A-B-C-D & 12 \\
\hline 11 & Taman Malabar & 0.53 & Kecil & 4 strata & A-B-C-D & 11 \\
\hline 12 & Taman Peranginan & 0.27 & Kecil & 4 strata & A-B-C-D & 10 \\
\hline 13 & Lapangan IPB Baranangsiang & 1.37 & Kecil & 3 strata & A-B-D & 9 \\
\hline 14 & Lapangan Empang & 0.3 & Kecil & 3 strata & A-C-D & 11 \\
\hline
\end{tabular}

Keterangan: Strata A (Pohon), B (Perdu), C (Semak), D (Penutup tanah dan merambat), E (Tumbuhan air)

ditemukan di Kebun Raya Bogor (57 jenis burung dari $32 \mathrm{suku}$ ) dan jumlah jenis burung terendah ditemukan di Lapangan Sempur (10 jenis burung dari 9 suku). Sementara itu, berdasarkan hasil pengamatan pada patch habitat berukuran kecil, jumlah jenis burung terbanyak ditemukan di Lapangan Manunggal (17 jenis burung dari 11 suku) dan jumlah jenis burung terendah ditemukan di Lapangan IPB Baranangsiang (9 jenis burung dari 9 suku). Berdasarkan hasil uji korelasi Pearson, diketahui bahwa terdapat hubungan yang cukup kuat antara kekayaan jenis burung dengan ukuran patch dengan nilai koefisien korelasi (R) sebesar $48.4 \%$.

Hasil pengamatan terhadap jenis burung unik menunjukkan bahwa patch habitat berukuran besar memiliki total 31 jenis burung unik. Sebanyak 22 jenis ditemukan di Kebun Raya Bogor, seperti Cicadaun Besar (Chloropsis sonnerati), Kipasan Belang (Rhipidura javanica), Perenjak Jawa (Prinia familiaris), Pelanduk Semak (Malacocincla sepiarium), dan Kucica Hutan (Copsychus malabaricus). Sebanyak enam jenis ditemukan di Ecopark CSC LIPI, seperti Wiwik Lurik (Cacomantis sonneratii), Manyar Tempua (Ploceus phillippinus), dan Mandar Batu (Gallinula chloropus). Sementara itu, tiga jenis lainnya ditemukan di Hutan Penelitian Dramaga, yaitu Cabai Bunga-api (Dicaeum trigonostigma), Srigunting Hitam (Dicrurus macrocercus), dan Kakatua Raja (Probosciger aterrimus). Selain itu, pada patch habitat berukuran kecil (Lapangan Manunggal) hanya ditemukan satu jenis burung unik, yaitu Merbah Belukar (Pycnonotus plumosus). Kipasan Belang dan Kakatua Raja termasuk jenis burung yang dilindungi menurut UndangUndang RI No. 5 Tahun 1990 dan Peraturan Pemerintah No. 7 Tahun 1999.

Seluruh patch habitat yang diamati memiliki jumlah strata dan jumlah jenis vegetasi bervariasi, yaitu 3-5 strata dan 11-282 jenis vegetasi (Gambar 2). Berdasarkan hasil pengamatan pada patch habitat kompleksitas 5 strata, jumlah jenis burung terbanyak ditemukan di Kebun Raya Bogor (57 jenis burung dari 32 suku) dan jumlah jenis burung terendah ditemukan di Sentul Boulevard (15 jenis burung dari 11 suku). Kebun Raya Bogor memiliki jumlah jenis vegetasi terbanyak, yaitu 282 jenis. Sementara itu, Sentul Boulevard tercatat memiliki 73 jenis vegetasi. Hasil pengamatan pada patch habitat kompleksitas 4 strata menunjukkan bahwa jumlah jenis burung terbanyak ditemukan di Ecopark CSC LIPI (28 jenis burung dari 16 suku) dan jumlah jenis burung terendah ditemukan di Lapangan Sempur serta Taman Peranginan (10 jenis burung dari 9 suku). Ecopark CSC LIPI tercatat memiliki 121 jenis vegetasi. Sementara itu, Lapangan Sempur dan Taman Peranginan berturut-turut tercatat memiliki 25 dan 29 jenis vegetasi. Selanjutnya, hasil pengamatan pada patch habitat kompleksitas 3 strata menunjukkan bahwa jumlah jenis burung terbanyak ditemukan di Lapangan Empang (11 jenis burung dari 9 suku) dan jumlah jenis burung terendah ditemukan di Lapangan IPB Baranangsiang (9 jenis burung dari $9 \mathrm{suku}$ ). Lapangan Empang tercatat memiliki 11 jenis vegetasi. Sementara itu, Lapangan IPB Baranangsiang tercatat memiliki 29 jenis vegetasi. Perbandingan jumlah jenis vegetasi terhadap kekayaan jenis burung dapat dilihat pada Gambar 3. Berdasarkan hasil uji korelasi Pearson, diketahui bahwa terdapat hubungan yang kuat antara kekayaan jenis burung dengan jumlah strata vegetasi dengan nilai koefisien korelasi (R) sebesar $58.1 \%$. Sementara itu, jumlah jenis vegetasi memiliki hubungan yang sangat kuat terhadap kekayaan jenis burung dengan koefisien korelasi (R) mencapai 96.6\%.

Hasil pengamatan terhadap pemanfaatan vegetasi oleh burung pada masing-masing strata menunjukkan bahwa strata pohon memiliki tingkat pemanfaatan tertinggi (55.14\%), dilanjutkan dengan strata semak $(15.89 \%)$, strata penutup tanah dan merambat $(14.02 \%)$, serta strata perdu $(11.21 \%)$. Sementara itu, strata tumbuhan air merupakan jenis strata yang memiliki tingkat pemanfaatan oleh burung terendah, yaitu sebesar $3.74 \%$. Pemanfaatan vegetasi oleh burung yang teridentifikasi berupa ingesti (makan, minum, defekasi, urinasi), lokomosi (berjalan, 


\section{WAHYUNI, SYARTINILIA, MULYANI}

loncat-loncat, memanjat), istirahat (bertengger, bersarang), membersihkan tubuh (menelisik, menggaruk, membersihkan paruh), agonistik, seksual, mematuk-matuk, dan bersuara (berkicau).
Berdasarkan hasil analisis regresi linier berganda, diketahui bahwa terdapat korelasi positif dengan keeratan hubungan yang sangat kuat antara kekayaan jenis burung dengan variabel patch habitat dengan nilai koefisien korelasi (R) sebesar $97 \%$ dan

Tabel 2 Jenis-jenis burung yang dijumpai di lokasi penelitian

\begin{tabular}{|c|c|c|}
\hline No & Nama Suku & Nama Ilmiah (Nama Lokal) \\
\hline 1 & Acanthizidae & 1) Gerygone sulphurea (Remetuk Laut) \\
\hline 2 & Aegithinidae & 2) Aegithina tiphia (Cipoh Kacat) \\
\hline 3 & Alcedinidae & $\begin{array}{l}\text { 3) Alcedo meninting (Rajaudang Meninting), 4) Halcyon chloris (Cekakak Sungai), } \\
\text { 5) Halcyon cyanoventris (Cekakak Jawa) }\end{array}$ \\
\hline 4 & Apodidae & 6) Apus nipalensis (Kapinis Rumah), 7) Collocalia linchi (Walet Linci) \\
\hline 5 & Ardeidae & 8) Nycticorax nycticorax (Kowakmalam Abu) \\
\hline 6 & Campephagidae & $\begin{array}{l}\text { 9) Lalage nigra (Kapasan Kemiri), 10) Pericrocotus cinnamomeus (Sepah Kecil), } \\
\text { 11) Tephrodornis virgatus (Jingjing Petulak) }\end{array}$ \\
\hline 7 & Capitonidae & 12) Megalaima haemacephala (Takur Ungkut-ungkut) \\
\hline 8 & Chloropseidae & 13) Chloropsis sonnerati (Cicadaun Besar) \\
\hline 9 & Columbidae & $\begin{array}{l}\text { 14) Geopelia striata (Perkutut Jawa), 15) Ptilinopus melanospila (Walik Kembang), } \\
\text { 16) Streptopelia chinensis (Tekukur Biasa), 17) Treron griseicauda (Punai Penganten), } \\
\text { 18) Treron vernans (Punai Gading) }\end{array}$ \\
\hline 10 & Cuculidae & $\begin{array}{l}\text { 19) Cacomantis merulinus (Wiwik Kelabu), 20) Cacomantis sepulcralis (Wiwik Uncuing), } \\
\text { 21) Cacomantis sonneratii (Wiwik Lurik) }\end{array}$ \\
\hline 11 & Dicaeidae & 22) Dicaeum trigonostigma (Cabai Bunga-api), 23) Dicaeum trochileum (Cabai Jawa) \\
\hline 12 & Dicruridae & 24) Dicrurus macrocercus (Srigunting Hitam) \\
\hline 13 & Estrildidae & $\begin{array}{l}\text { 25) Lonchura leucogastroides (Bondol Jawa), 26) Lonchura maja (Bondol Haji), } \\
\text { 27) Lonchura punctulata (Bondol Peking) }\end{array}$ \\
\hline 14 & Hirundinidae & 28) Hirundo striolata (Layanglayang Loreng), 29) Hirundo tahitica (Layanglayang Batu) \\
\hline 15 & Laniidae & 30) Lanius cristatus (Bentet Coklat), 31) Lanius schach (Bentet Kelabu) \\
\hline 16 & Monarchidae & 32) Rhipidura javanica (Kipasan Belang) \\
\hline 17 & Muscicapidae & 33) Ficedula westermanni (Sikatan Belang), 34) Muscicapa dauurica (Sikatan Bubik) \\
\hline 18 & Nectariniidae & $\begin{array}{l}\text { 35) Anthreptes malacensis (Burungmadu Kelapa), 36) Arachnothera longirostra (Pijantung } \\
\text { Kecil), 37) Cinnyris jugularis (Burungmadu Sriganti) }\end{array}$ \\
\hline 19 & Oriolidae & 38) Oriolus chinensis (Kepudang Kuduk-hitam) \\
\hline 20 & Paridae & 39) Parus major (Gelatikbatu Kelabu) \\
\hline 21 & Phalacrocoracidae & 40) Anhinga melanogaster (Pecukular Asia) \\
\hline 22 & Picidae & 41) Dendrocopos macei (Caladi Ulam), 42) Dendrocopos moluccensis (Caladi Tilik) \\
\hline 23 & Ploceidae & 43) Passer montanus (Burunggereja Erasia), 44) Ploceus phillippinus (Manyar Tempua) \\
\hline 24 & Psittacidae & 45) Probosciger aterrimus (Kakatua Raja), 46) Psittacula alexandri (Betet Biasa) \\
\hline 25 & Pycnonotidae & $\begin{array}{l}\text { 47) Criniger bres (Empuloh Janggut), 48) Pycnonotus atriceps (Cucak Kuricang), } \\
\text { 49) Pycnonotus aurigaster (Cucak Kutilang), 50) Pycnonotus brunneus (Merbah Mata-merah), } \\
\text { 51) Pycnonotus goiavier (Merbah Cerukcuk), 52) Pycnonotus melanicterus (Cucak Kuning), } \\
\text { 53) Pycnonotus plumosus (Merbah Belukar) }\end{array}$ \\
\hline 26 & Rallidae & 54) Amaurornis phoenicurus (Kareo Padi), 55) Gallinula chloropus (Mandar Batu) \\
\hline 27 & Sittidae & 56) Sitta frontalis (Munguk Beledu) \\
\hline 28 & Sturnidae & 57) Acridotheres javanicus (Kerak Kerbau) \\
\hline 29 & Sylviidae & $\begin{array}{l}\text { 58) Cisticola juncidis (Cici Padi), 59) Orthotomus ruficeps (Cinenen Kelabu), 60) Orthotomus } \\
\text { sepium (Cinenen Jawa), 61) Orthotomus sutorius (Cinenen Pisang), 62) Phylloscopus borealis } \\
\text { (Cikrak Kutub), 63) Prinia familiaris (Perenjak Jawa) }\end{array}$ \\
\hline 30 & Timaliidae & $\begin{array}{l}\text { 64) Macronous flavicollis (Ciungair Jawa), 65) Malacocincla sepiarium (Pelanduk Semak), } \\
\text { 66) Pellorneum capistratum (Pelanduk Topi-hitam), 67) Timalia pileata (Tepus Gelagah) }\end{array}$ \\
\hline 31 & Turdidae & 68) Copsychus malabaricus (Kucica Hutan) \\
\hline 32 & Turnicidae & 69) Turnix suscitator (Gemak Loreng) \\
\hline 33 & Zosteropidae & 70) Zosterops palpebrosus (Kacamata Biasa) \\
\hline
\end{tabular}


nilai koefisien determinasi $\left(\mathrm{R}^{2}\right)$ sebesar 94.1\%. Hasil uji $\mathrm{F}$ menunjukkan bahwa model pendugaan hubungan yang dihasilkan dapat diterima $(p<0.001)$. Berdasarkan analisis ini, diketahui bahwa variabel patch habitat yang berpengaruh nyata terhadap kekayaan jenis burung di Kota Bogor dan sekitarnya adalah jumlah jenis vegetasi. Sementara itu, dua variabel lainnya, yaitu ukuran patch dan jumlah strata vegetasi diketahui tidak berpengaruh nyata terhadap kekayaan jenis burung di Kota Bogor dan sekitarnya. Model pendugaan hubungan antara kekayaan jenis burung dengan variabel patch habitat adalah sebagai berikut.

$$
\mathrm{Y}=11.783+0.180 \mathrm{X}
$$

Keterangan:

$\mathrm{Y}=$ Jumlah jenis burung

$X=$ Jumlah jenis vegetasi

\section{Pembahasan}

Secara umum, variabel paling penting yang berpengaruh terhadap kekayaan jenis burung di Kota Bogor dan sekitarnya adalah jumlah jenis vegetasi (kompleksitas patch). Hasil ini sejalan dengan hasil studi yang dilakukan di lanskap perkotaan di Swiss (Fontana et al., 2011) dan Israel (Paker et al., 2014), kekayaan jenis vegetasi memiliki pengaruh yang signifikan terhadap jumlah jenis burung di lanskap perkotaan. Menurut
Ontario et al. (1991), vegetasi merupakan komponen habitat yang dapat memberikan berbagai macam fungsi bagi burung. Semakin tinggi tingkat keragaman struktur vegetasi di suatu habitat, maka akan semakin tinggi pula tingkat kekayaan satwa di habitat tersebut (Dramstad et al., 1996). Menurut Beck (2013), salah satu upaya untuk meningkatkan kekayaan jenis adalah dengan meningkatkan keragaman habitat mikro. Habitat yang kompleks berkaitan dengan ketersediaan pakan yang beragam bagi burung. Hal ini berarti bahwa semakin kompleks suatu habitat, yang ditandai dengan banyaknya jumlah jenis vegetasi, maka semakin tinggi pula ketersediaan pakan dan relung habitat bagi burung. Tingginya ketersediaan pakan dan relung habitat tersebut, dapat meningkatkan daya dukung habitat dalam mendukung kelangsungan hidup burung, khususnya di lanskap perkotaan. Selain itu, Forman dan Godron (1986) juga menyatakan bahwa suatu lanskap yang memiliki keragaman rendah, cenderung rentan terhadap gangguan yang terjadi. Jika terjadi suatu gangguan dalam suatu lanskap dengan keragaman rendah, maka kemungkinan terjadinya kerusakan lanskap, penurunan kualitas lanskap, bahkan kepunahan akan semakin besar.

Lebih lanjut, jenis vegetasi yang memiliki pengaruh besar terhadap kekayaan jenis burung di Kota Bogor dan sekitarnya adalah vegetasi dari strata pohon. Pada studi yang dilakukan oleh Fontana et al. (2011), diketahui bahwa jumlah vegetasi dari strata pohon merupakan variabel paling penting yang dapat

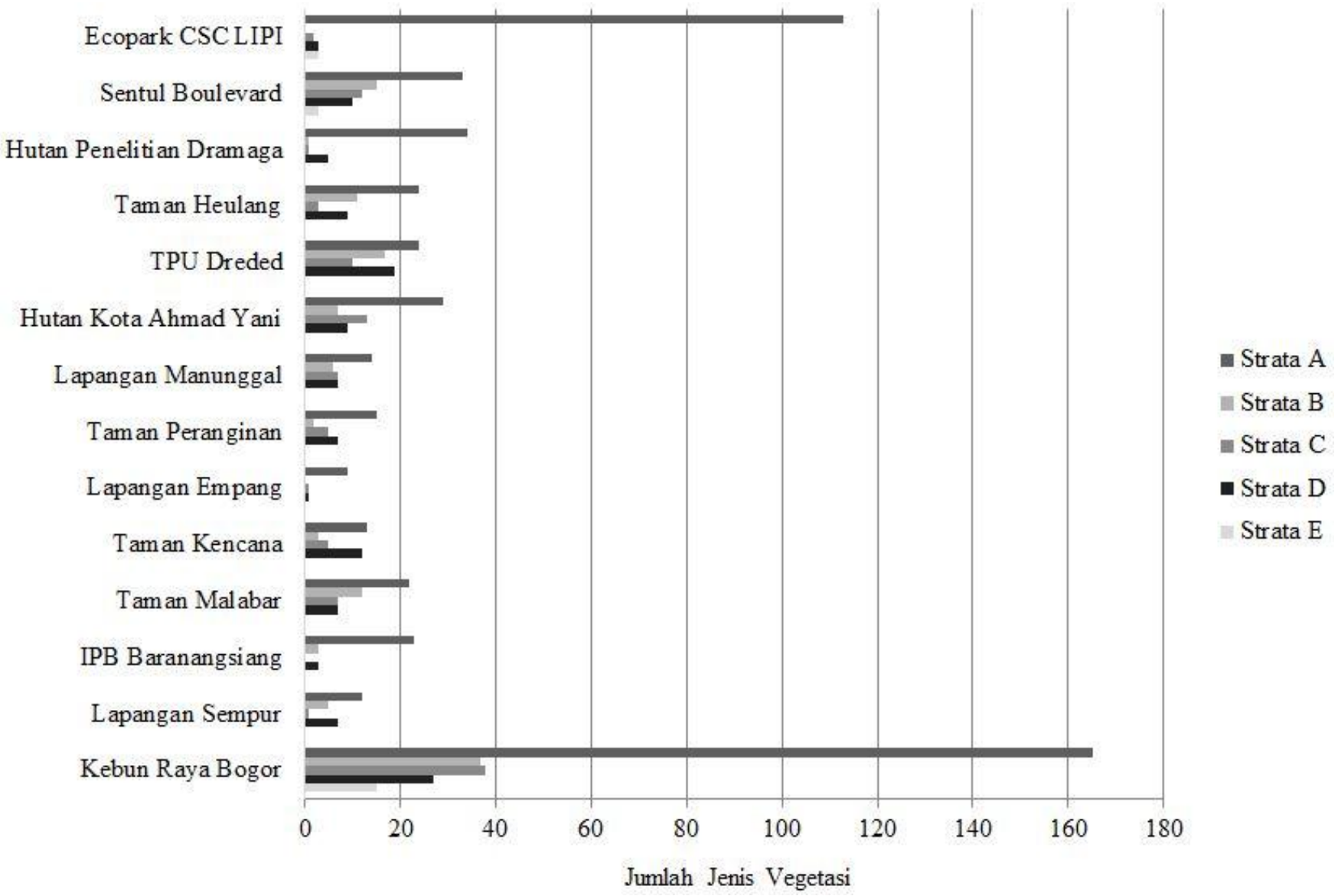

Gambar 2. Perbandingan jumlah jenis vegetasi pada tiap strata di masing-masing patch habitat 


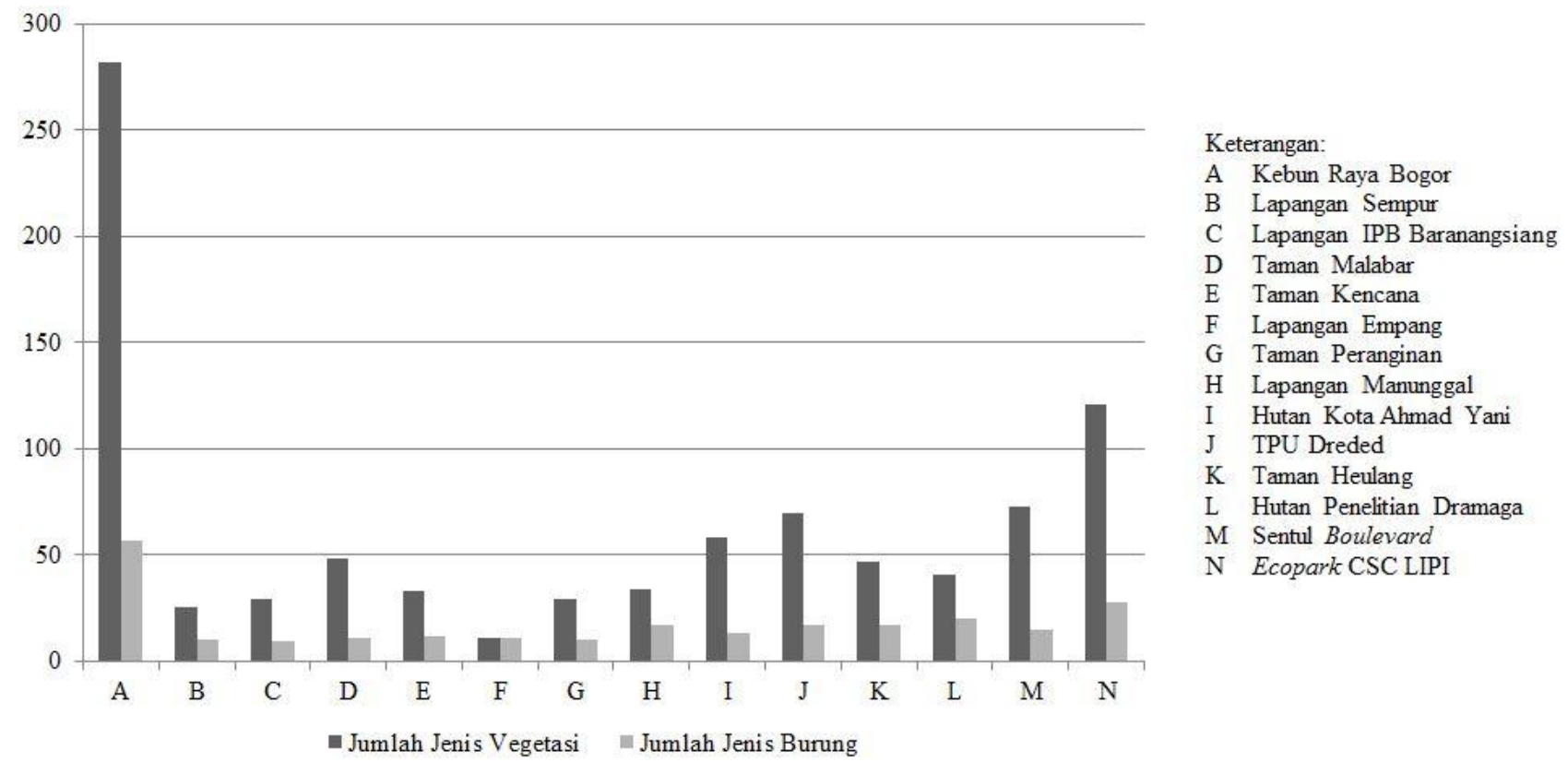

Gambar 3. Perbandingan jumlah jenis vegetasi terhadap kekayaan jenis burung di masing-masing patch habitat

meningkatkan kekayaan jenis burung di tiga kota di Swiss. Berdasarkan model prediksi yang dikembangkan berdasarkan studi tersebut, diketahui bahwa peningkatan sebesar $46 \%$ area bervegetasi pohon, dapat meningkatkan kekayaan jenis burung sebesar 54\%. Pada lanskap perkotaan, tingkat gangguan pada patch-patch habitat yang dapat mempengaruhi kekayaan jenis burung tergolong tinggi, seperti infrastruktur jalan, lalu lintas kendaraan, tingkat kebisingan, dan pejalan kaki yang melintas (Carbó-Ramírez dan Zuria, 2011). Faktor-faktor tersebut menyebabkan pemanfaatan strata vegetasi oleh burung di lanskap perkotaan cenderung dominan pada strata pohon (Carbó-Ramírez dan Zuria, 2011; Fontana et al., 2011; Paker et al., 2014).

Menurut August (1983), kompleksitas habitat dicirikan oleh keragaman struktur vertikal (strata vegetasi) di dalam habitat tersebut. Suatu lanskap yang memiliki keragaman vegetasi yang tinggi, cenderung memiliki kualitas yang lebih baik (Dyke, 2003). Hal ini juga berlaku pada skala yang lebih kecil, meningkatnya keragaman strata vegetasi pada patch habitat, akan meningkatkan kualitas patch habitat tersebut. Namun, pada penelitian ini, variabel jumlah strata vegetasi diketahui tidak berpengaruh signifikan terhadap kekayaan jenis burung di Kota Bogor dan sekitarnya. Hal ini dapat disebabkan karena burung di lanskap perkotaan cenderung lebih sensitif terhadap keberadaan vegetasi strata tertentu, yaitu strata pohon dan perdu (Donnelly dan Marzluff, 2006; MacGregor-Fors dan Schondube, 2011; Paker et al., 2014). Meskipun jumlah strata vegetasi tidak memiliki pengaruh nyata terhadap kekayaan jenis burung, namun variabel ini tidak bisa diabaikan. Hasil pengamatan terhadap jenis burung unik menunjukkan bahwa seluruh jenis burung unik hanya ditemukan pada patch habitat dengan kompleksitas 4 dan 5 strata. Hal ini menunjukkan bahwa jumlah strata vegetasi dapat menjadi salah satu faktor bagi keberadaan jenis burung unik di lanskap perkotaan. Pada penelitian ini, terdapat satu jenis burung unik yang merupakan jenis introduksi, yaitu Kakatua Raja (Probosciger aterrimus). Kakatua Raja memiliki daerah persebaran di Indonesia (Papua dan Kepulauan Aru), Papua Nugini, dan Australia (Queensland) (Murphy et al., 2003; Sukmantoro et al., 2007).

Menurut Beck (2013), semakin besar luasan suatu area, maka semakin tinggi kekayaan jenis spesies yang ada di dalamnya. Namun, pada penelitian ini, variabel ukuran patch habitat diketahui tidak berpengaruh signifikan terhadap kekayaan jenis burung di Kota Bogor dan sekitarnya. Hasil ini sejalan dengan hasil studi yang dilakukan oleh Kim et al. (2007), luasan ruang terbuka hijau yang berperan sebagai habitat burung tidak berpengaruh signifikan terhadap jumlah jenis burung di lanskap perkotaan Seoul, Korea Selatan. Ukuran patch bukanlah satu-satunya faktor yang dapat menjadi penciri tinggi atau rendahnya kekayaan jenis burung pada suatu patch habitat. Menurut Carbó-Ramírez dan Zuria (2011), terdapat faktorfaktor lainnya yang dapat mempengaruhi kekayaan jenis burung di suatu patch habitat, seperti kondisi lanskap sekitar dan gangguan dari manusia. Patch habitat berukuran kecil, bisa saja memiliki kekayaan jenis burung yang lebih tinggi dibandingkan dengan patch habitat berukuran besar. Pada penelitian ini, patch habitat berukuran besar, yaitu Lapangan Sempur, memiliki kekayaan jenis burung lebih rendah dibandingkan dengan Lapangan Manunggal yang merupakan patch habitat berukuran kecil. Dilihat dari kompleksitas patchnya, meskipun memiliki jumlah strata vegetasi yang sama, namun terdapat perbedaan jumlah jenis vegetasi yang cukup signifikan antara Lapangan Sempur dan Manunggal. Jumlah jenis vegetasi di Lapangan Sempur lebih rendah dibandingkan dengan jumlah jenis vegetasi di Lapangan Manunggal. Hal ini menunjukkan bahwa keberadaan patch habitat berukuran kecil sama pentingnya dengan patch habitat berukuran besar dalam menjaga kelangsungan hidup burung di lanskap perkotaan. Menurut Dramstad et al. (1996), patch habitat berukuran kecil dapat mendukung spesies yang tidak biasa dan memfasilitasi 
pergerakan spesies dari satu patch ke patch lainnya. Selain itu, patch habitat berukuran kecil juga memiliki nilai penting untuk mendukung patch habitat berukuran besar (Kim et al., 2006). Namun, dalam pengembangannya, patch berukuran kecil lebih realistis untuk dikembangkan sebagai habitat burung di lanskap perkotaan. Hal ini disebabkan oleh adanya faktor keterbatasan penyediaan lahan untuk RTH karena tingginya harga lahan, tingkat fragmentasi lahan, dan densitas ruang terbangun (Lee dan Kim, 2015). Namun, patch habitat berukuran kecil tersebut dapat ditingkatkan efektivitasnya sebagai patch habitat burung di lanskap perkotaan melalui upaya peningkatan kompleksitas patch habitat, terutama jumlah jenis vegetasi dan jumlah strata vegetasi.

\section{Rekomendasi Pengelolaan}

Dari hasil studi yang dilakukan terhadap efektivitas RTH sebagai patch habitat burung, dapat disusun beberapa rekomendasi untuk pengelolaan $\mathrm{RTH}$ sebagai patch habitat burung di lanskap perkotaan, khususnya di Kota Bogor dan sekitarnya, yaitu: 1) Patch habitat berukuran kecil dan besar, terutama patch yang berupa taman dan lapangan seperti Taman Heulang, Taman Kencana, Taman Malabar, Taman Peranginan, Lapangan Sempur, Lapangan Manunggal, Lapangan IPB Baranangsiang, serta Lapangan Empang, perlu dipertahankan keberadaannya karena baik patch berukuran besar maupun kecil, memiliki fungsi penting sebagai habitat burung; 2) Patch habitat berukuran kecil dengan kompleksitas tiga strata vegetasi, yaitu Lapangan IPB Baranangsiang (1.37 ha) dan Lapangan Empang (0.3 ha), perlu ditingkatkan kualitasnya dengan cara menambah jumlah strata vegetasi dan/atau jumlah jenis vegetasi pada strata tertentu. Hal ini dapat menambah relung habitat dan ketersediaan sumberdaya pakan bagi burung sehingga dapat mengundang jenis burung lainnya; 3) Patch habitat berukuran besar dengan kompleksitas empat dan lima strata vegetasi namun memiliki kekayaan jenis burung rendah, yaitu Lapangan Sempur (2.2 ha) dan Sentul Boulevard (33.71 ha), perlu ditingkatkan kualitasnya dengan cara menambah jumlah jenis vegetasi pada strata tertentu yang dapat menyediakan kebutuhan burung. Secara umum, efektivitas RTH sebagai patch habitat burung di lanskap perkotaan, terutama RTH yang berukuran kecil (lebih umum dijumpai di lanskap perkotaan dibandingkan dengan RTH yang berukuran besar), dapat ditingkatkan melalui upaya peningkatan jumlah jenis vegetasi dan jumlah strata vegetasi.

\section{KESIMPULAN}

Berdasarkan hasil analisis efektivitas RTH sebagai patch habitat burung, dapat disimpulkan bahwa 1) ukuran patch habitat tidak memiliki pengaruh yang signifikan terhadap kekayaan jenis burung di lanskap perkotaan, 2) kompleksitas patch habitat variabel jumlah strata vegetasi tidak memiliki pengaruh yang signifikan terhadap kekayaan jenis burung di lanskap perkotaan, namun dapat menjadi salah satu faktor bagi keberadaan jenis burung unik, serta 3) kompleksitas patch habitat variabel jumlah jenis vegetasi memiliki pengaruh terhadap kekayaan jenis burung. Patch habitat berukuran kecil dapat mendukung fungsi patch habitat berukuran besar. Bahkan di beberapa lokasi, patch habitat berukuran kecil memiliki kekayaan jenis burung yang lebih tinggi. Hal ini menunjukkan bahwa keberadaan patch berukuran kecil sama pentingnya dengan patch berukuran besar, khususnya di lanskap perkotaan. Beberapa rekomendasi yang dihasilkan, yaitu: 1) mempertahankan keberadaan patch habitat berukuran kecil dan besar karena keduanya berfungsi penting sebagai habitat burung di lanskap perkotaan, 2) menambah jumlah strata vegetasi dan/atau jumlah jenis vegetasi pada strata tertentu pada patch habitat dengan kompleksitas tiga strata, serta 3) menambah jumlah jenis vegetasi pada strata tertentu pada patch habitat dengan kompleksitas empat dan lima strata namun memiliki kekayaan jenis burung rendah.

\section{DAFTAR PUSTAKA}

August, P.V. 1983. The Role of Habitat Complexity and Heterogeneity in Structuring Tropical Mammal Communities. Ecology. 64(6)1495-1507.

Beck, T. 2013. Principles of Ecological Landscape Design. Washington: Island Pr.

Bibby, C.J. 2004. Bird Diversity Survey Methods. Di dalam: Sutherland, W.J., Newton, I., Green, R.E. 2004. Bird Ecology and Conservation: A Handbook of Techniques. New York: Oxford Univ Pr. Hal: 1-15.

Bullock, J.M. 2006. Plants. Di dalam: Sutherland, W.J. 2006. Ecological Census Techniques. 2nd ed. Cambridge: Cambridge Univ. Hal: 186-213.

[CABE] Commission for Architecture and the Built Environment. 2009. Open Space Strategies: Best Practice Guide. London: CABE.

Carbó-Ramírez, P., Zuria, I. 2011. The Value of Small Urban Greenspaces for Birds in a Mexican City. Landscape and Urban Planning. 100(2011):213-222.

Chiesura, A. 2004. The Role of Urban Parks for the Sustainable City. Landscape and Urban Planning. 68(1):129-138.

Diamond, J.M., Bishop, K.D., Van Balen, S. 1987. Bird Survival in an Isolated Javan Woodland: Island or Mirror?. Conservation Biology. 1(4):132-142.

Donnelly, R., Marzluff, J.M. 2006. Relative Importance of Habitat Quantity, Structure, and Spatial Pattern to Birds in Urbanizing Environment. Urban Ecosystem. 9(2006):99-117. 
Dramstad, W.E., James, D.O., Forman, R.T.T. 1996. Landscape Ecology Principles in Landscape Architecture and Land-Use Planning. Washington: Island Pr.

Dyke, F.V. 2003. Conservation Biology: Foundations, Concepts, Applications. New York: McGraw-Hill Companies, Inc.

Endah, G.P.,Partasasmita, R. 2015. Keanekaan Jenis Burung di Taman Kota Bandung, Jawa Barat. Prosiding Seminar Nasional Masyarakat Biodiversitas Indonesia. 6(1):1289-1294.

Fontana, S., Sattler, T., Bontadina, F., Moretti, M. 2011. How to Manage the Urban Green to Improve Bird Diversity and Community. Landscape and Urban Planning. 101(2011):278285.

Forman, R.T.T., Godron, M. 1986. Landscape Ecology. New York: John Wiley and Sons.

Furness, R.W., Greenwood, J.J.D., Jarvis, P.J. 1993. Birds as Monitors of Environmental Change. Furness, R.W., Greenwood, J.J.D., editor. London: Chapman \& Hall.

Irwan, Z.D. 2012. Prinsip-prinsip Ekologi: Ekologi, Lingkungan, dan Pelestariannya. Jakarta: Bumi Aksara.

Kim, J., Chae, J., Koo, T.H. 2007. Variation in Bird Diversity in Relation to Habitat Size in the Urban Landscape of Seoul, South Korea. Acta Ornithologica. 42(1):39-44.

Koskimies, P. 1989. Birds as A Tool in Environmental Monitoring. Annales Zoologici Fennici. 26(1989):153-166.

Lee, Y.C., Kim, K.H. 2015. Attitudes of Citizens towards Urban Parks and Green Open Spaces for Urban Sustainability: The Case of Gyeongsan City, Republic of Korea. Sustainability. 7(7):8240-8254.

[LIPI] Lembaga Ilmu Pengetahuan Indonesia. 2013. 3500 Plant Species of The Botanic Gardens of Indonesia. Jakarta: LIPI.

MacGregor-Fors, I., Schondube, J.E. 2011. Gray vs Green Urbanization: Relative Importance of Urban Features for Urban Bird Communities. Basic and Applied Ecology. 12(2011):372-381.

Murphy, S., Legge, S., Heinsohn, R. 2003. The Breeding Biology of Palm Cockatoos (Probosciger aterrimus): A Case of a Slow Life History. Zoology. 261(2003):327-339.

Nichol, J.E., Wong, M.S., Corlett, R., Nichol, D.W. 2010. Assessing Avian Habitat Fragmentation in Urban Areas of Hongkong (Kowloon) at High Spatial Resolution using Spectral Unmixing. Landscape and Urban Planning. 95(2010):54-60.

Nilon, C.H., Berkowitz, A.R., Hollweg, K.S. 2003. Understanding Urban Ecosystems: A New Frontier for Science and Education. New York: Springer-Verlag New York, Inc.
Ontario, J., Hernowo, J.B., Haryanto, Ekarelawan. 1991. Pola Pembinaan Habitat Burung di Kawasan Pemukiman Terutama di Perkotaan. Bogor: Jurusan Konservasi Sumberdaya Hutan, Fakultas Kehutanan, Institut Pertanian Bogor.

Paker, Y., Yom-Tov, Y., Alon-Mozes, T., Barnea, A. 2014. The Effect of Plant Richness and Urban Garden Structure on Bird Speciess Richness, Diversity, and Community Structure. Landscape and Urban Planning. 122(2014):186195.

Parsons, H. 2007. Best Practice Guidelines for Enhancing Urban Bird Habitat. Birds in Backyards Program. New South Wales

Robertson, P.A., Liley, D. 1998. Assessment of Sites: Measurement of Species Richness and Diversity. Di dalam: Bibby, C., Jones, M., Marsden, S. 1998. Expedition Field Techniques: Bird Surveys. London: Expedition Advisory Centre. Hal: 80-102.

Setiawan, A., Alikodra, H.S., Gunawan, A., Darnaedi, D. 2006. Keanekaragaman Jenis Pohon dan Burung di Beberapa Hutan Kota Bandar Lampung. Jurnal Manajemen Hutan Tropika. 12(1):1-13.

Simonds, J.O., Starke, B.W. 2006. Landscape Architecture: A Manual of Environmental Planning and Design. 4th ed. New York: McGraw-Hill Companies, Inc.

Sukara, G.N., Mulyani, Y.A., Muntasib, E.K.S.H. 2014. Potensi untuk Pengembangan Wisata "Birdwatching" di Pusat Konservasi Tumbuhan Kebun Raya Bogor. Buletin Kebun Raya. 17(1):44-56.

Sukmantoro, W., Irham, M., Novarino, W., Hasudungan, F., Kemp, N., Muchtar, M. 2007. Daftar Burung Indonesia No.2. Bogor: Indonesian Ornitologists Union.

Strohbach, M.W., Lerman, S.B., Warren, P.S. 2013. Are Small Greening Areas Enhancing Bird Diversity? Insights from Community-driven Greening Projects in Boston. Landscape and Urban Planning. 114(2013):69-79. 